\title{
Validity of Biochemical Teaching Material Equipped by Research Result of Biology Students
}

\author{
Yuliza $^{1}$, Wilny Okta ${ }^{1(*)}$, Putri $^{1}$, Dwi Hilda ${ }^{1}$, Advinda $^{1}$, Linda $^{1}$ \\ ${ }^{1}$ Post Graduate Program of Biology Educations, Universitas Negeri Padang, Indonesia \\ "Corresponding author.Email: wilny.oktayuliza@gmail.com, dwi_hildaputri@yahoo.com
}

\begin{abstract}
Introduction- the biochemical course is related to biology because biochemical discusses chemical processes that occur in the body of human being. Based on the results of the questionnaire, it was known that students did not have preparations before the lecture. Therefore, it was necessary to have biochemical teaching materials that help students to learn the material before lectures. Research results related to the material could be added to the teaching materials thus they can provide examples in the form of facts in lectures. PurposeThe purpose of this research is to produce biochemical teaching materials equipped by research results with valid criteria. Methods-Development research used the Plomp model. Validation of teaching materials was seen from the aspects of content, presentation, graphics, and language. Results-Assessment of the aspect of content obtained valid criteria with a value of $80 \%$, aspects of presentation and graphics obtained valid criteria with a value of $75 \%$, and aspects of language obtained very valid criteria with a value of $81.25 \%$. Recommendation-The biochemical teaching materials developed have met valid criteria thus they can be used in biochemical lectures and materials can be used by students as an independent learning.
\end{abstract}

\section{Keywords: Validity, Biochemical, Teaching Materials, Research Results, Biology Students.}

\section{INTRODUCTION}

Biology is one of the basic sciences that determines the progress and development of science and technology because by learning biology we will have the ability to think logically, systematically and creatively in solving problems. One of the compulsory subjects in the Department of Biology, FMIPA UNP is Biochemical. The biochemical course is closely related to biological sciences because biochemical discusses the chemical processes that occur in the body of living things.

After participated in biochemical courses, students were expected to be able to understand and explain the chemical reactions and mechanisms that occur in the body, on the other hand, biology students must also be able to apply biochemical to the biological processes that occur in the body.

Biochemical learning should be of interest to students because in biochemical material students learn reactions that occur in their own bodies. Based on the data that were obtained from the questionnaires to biology students, students still consider biochemical material was difficult to understand. This is in accordance with the research of [1] stated that one of the topics that is difficult for students is the material of aerobic respiration metabolism, this material is part of the biochemical material.
Based on interviews with lecturers, it was known that the lecturers have not used teaching materials that were appropriate with the biochemical material that needs to be studied. Students were encouraged to look for references related to biochemical material.

Teaching materials commonly used by lecturers during lectures were powerpoint slides. Teaching materials in the form of powerpoint slide only present material concepts in general, while biochemical material is complex and has much material. Besides the lecturers' explanations, students also need further information about the material that students can learn again independently. Therefore, another written guide is needed that can be used by students in lectures, in the form of structured teaching materials in accordance with the material to be studied.

Teaching materials are all forms of material used to assist teachers in carrying out teaching and learning activities[2]. One component of teaching materials according to the [2] is the existence of supporting information. Supporting information related to the material can help students understand lecture material.

Supporting information that can be added to teaching materials is in the form of research results. Utilizing the results of research in teaching materials can provide real examples in lectures. [3] stated the results of research that have been published in journals are feasible to be used in 
reference to the development of teaching materials because they are more applicable.

According to [3] using teaching materials based on research results can foster interest and motivation thus it can reduce the boredom of students because learning material is associated with the results of research thus it is applicable. Learning based on the results of research not only comes from the research of the lecturers themselves but the need for sharing between academics regarding the results of research as transfer and development of knowledge in universities [4].

Based on the data that were presented, it was necessary to develop biochemical teaching materials equipped by the result of the research for biology students. Before being used, the teaching materials developed were first validated by experts, thus it produced valid teaching materials. Therefore, it was necessary to attempt the validity of the instructional materials developed.

\section{THEORITICAL REVIEW}

\subsection{Validity}

Validity is a criterion for the validity of the product that was produced. According to[5], validity is concerned with the accuracy of the measurement tools for the measured concept thus it really measures the things that need to be measured. [6] stated that validity refers to the accuracy, meaningfulness, and usefulness of a conclusion that was stated by an expert. [2] stated that the evaluation component includes the feasibility of content, language, presentation, and graphics.

\subsection{Teaching Materials}

Teaching materials are information, written tools and written and non-written texts that systematically arranged, used to help educators in carrying out teaching and learning activities in order to create an environment or atmosphere that allows students to learn effectively. Teaching materials are a collection of learning materials that are arranged into a unit based on competencies that need to be mastered by the students..

Teaching materials enable the students to learn a material in a coherent and systematic manner thus accumulatively able to master all competencies as a whole and integrated [4]. Teaching materials can also help students in the learning process thus the students are not dependent on the teacher as the only source of information.

Research is an important means to improve the quality of learning. All of these are important meanings that can be seen from several perspectives, problem formulations, problem-solving, and communicating the benefits of research results. This is believed to be able to improve the quality of learning. Research-based learning is learning that uses authentic learning, problem-solving cooperative learning, contextual guided by the philosophy of constructivism [7]. According to [8] all undergraduate students and all educational institutions must learn through the search and investigation. Learning from research means that students can gain knowledge about theory and important research in their disciplines.

Some strategies that can be used to link empirical learning and research developed at [9], namely 1) Enriching teaching materials using the results of lecturer research, 2) Using the latest research findings, 3) Enriching learning with contemporary research issues, 4 ) Teaching research methodology material in learning, 5) Enriching learning by, 6) Enriching learning by involving students in institutional research activities, 7) Enriching learning by encouraging students to feel part of the research culture in faculties / departments, 8) Enriching learning with values that must be possessed by the researchers.

\section{RESEARCH METHODS}

This type of research is development research (design and development research). The products developed were biochemical teaching materials equipped by the results of the research. This study used the Plomp model which consists of three stages, namely the initial investigation phase (preliminary research phase), (2) the prototype phase, (3) the assessment phase [10].

At the preliminary research stage, an analysis of the problems and characteristics of students in biochemical lectures was conducted by interviewing lecturers and distributing questionnaires to students and analyzing the needs of students on biochemical teaching materials. Next was the development phase of the prototype. The prototype compiled based on preliminary research data was still in the form of prototype 1, which was first evaluated by itself to see obvious errors and check the completeness of the components of the instructional materials that were developed. Based on the results of selfevaluation, revisions were made to produce prototype II. The prototype is then validated by the expert in their field.

Validation of teaching materials was conducted to produce valid biochemical teaching materials. Validated components were aspects of content, language, graphics, and presentation. Each aspect was validated by a different expert, it consisted of four experts. List of the names of validators that validated the teaching materials could be seen in Table 1.

Table 1: List of validator names.

\begin{tabular}{|c|c|}
\hline Validated Aspect & Validator Name \\
\hline Feasibility of content & Dr, Violita, M. Si. \\
\cline { 2 - 2 } & Dr. Hardeli, M. Si. \\
\hline Linguistics & $\begin{array}{c}\text { Dr. Abdurrahman, M. } \\
\text { Pd. }\end{array}$ \\
\hline Presentation & Dr. Darmansyah, M. Pd. \\
\hline Graphics & \\
\hline
\end{tabular}

Validation used validity test instruments, before being used, the validity test instrument was first validated by the experts, thus the instruments that were used could 
measure the validity of teaching material. The results of instrument validation can be seen in Table 2 .

Table 2: Results of instrument validation test validity.

\begin{tabular}{|c|c|c|c|c|}
\hline Validated aspect & \multicolumn{2}{|c|}{$\begin{array}{c}\text { Valid } \\
\text { ators }\end{array}$} & $\begin{array}{c}\text { Avera } \\
\text { ge }\end{array}$ & Category \\
\cline { 2 - 5 } & 1 & 2 & & \\
\hline $\begin{array}{c}\text { The instructions } \\
\text { for filling out the } \\
\text { questionnaire are } \\
\text { easy to understand }\end{array}$ & 4 & 3 & 3,5 & Very Valid \\
\hline $\begin{array}{c}\text { Suitability of the } \\
\text { grid with statement } \\
\text { items }\end{array}$ & 4 & 3 & 3,5 & Very Valid \\
\hline $\begin{array}{c}\text { Item statements } \\
\text { using good and } \\
\text { correct Indonesian }\end{array}$ & 3 & 3 & 3 & Valid \\
\hline $\begin{array}{c}\text { There is a } \\
\text { statement } \\
\text { regarding the } \\
\text { component } \\
\text { contents }\end{array}$ & 3 & 3 & 3 & Valid \\
\hline $\begin{array}{c}\text { There is a } \\
\text { statement } \\
\text { regarding the } \\
\text { graphic component }\end{array}$ & 3 & 3 & 3 & Valid \\
\hline $\begin{array}{c}\text { There is a } \\
\text { statement about the } \\
\text { language } \\
\text { component }\end{array}$ & 3 & 3 & 3 & Valid \\
\hline $\begin{array}{c}\text { There is a } \\
\text { statement } \\
\text { regarding the } \\
\text { presentation } \\
\text { component }\end{array}$ & 3 & 3 & 3 & Valid \\
\hline Average & & & & \\
\hline
\end{tabular}

Based on the results of the validator's assessment, the validity instrument was stated to be very valid, it means that the instrument could be used to measure the validity of an instructional material developed.

The data that were obtained from this research were the results of the validation of teaching materials seen in four aspects, namely aspects of content, language, graphics, and presentation.

Determination of answer scores based on likert scale criteria adapted by Riduwan (2012), as follows.

$$
\begin{array}{ll}
4 & =\text { Strongly agree (SS) } \\
3 & =\text { Agree (S) } \\
2 & =\text { Less disagree (KS) } \\
1 & =\text { Disagree (TS) }
\end{array}
$$

After that, determined the value of validity by Validity value $=\frac{\text { number of scores obtained }}{\text { highest number of scores }} x 100 \%$
After validated the value of validity, then validity criteria were determined using the modified assessment criteria from Riduwan (2012) as follows:

$$
\begin{array}{ll}
0-20 \% & =\text { invalid } \\
21-40 \% & =\text { less valid } \\
41-60 \% & =\text { enough valid } \\
61-80 \% & =\text { Valid } \\
81-100= & \text { very valid }
\end{array}
$$

\begin{tabular}{|c|c|c|c|c|}
\hline \multirow[t]{2}{*}{ Validated aspect } & \multicolumn{2}{|c|}{$\begin{array}{c}\text { Validat } \\
\text { or }\end{array}$} & \multirow{2}{*}{$\begin{array}{c}\text { Valid } \\
\text { atio } \\
\mathrm{n} \\
\text { valu } \\
\mathrm{e} \\
(\%)\end{array}$} & \multirow{2}{*}{ Category } \\
\hline & 1 & 2 & & \\
\hline $\begin{array}{l}\text { Material presentation } \\
\text { refers to the } \\
\text { Indonesian National } \\
\text { Qualifications } \\
\text { Framework (KKNI }\end{array}$ & 3 & 3 & 75 & Valid \\
\hline $\begin{array}{c}\text { Material } \\
\text { development in } \\
\text { accordance with } \\
\text { Learning Outcome } \\
\text { (LO) }\end{array}$ & 3 & 3 & 75 & Valid \\
\hline $\begin{array}{l}\text { The material } \\
\text { developed according } \\
\text { to the LO want to } \\
\text { achieve in } \\
\text { biochemical courses }\end{array}$ & 3 & 3 & 75 & Valid \\
\hline $\begin{array}{l}\text { The substance of the } \\
\text { material developed } \\
\text { has the truth of the } \\
\text { concept }\end{array}$ & 3 & 3 & 75 & Valid \\
\hline $\begin{array}{l}\text { Material substance } \\
\text { could add insight to } \\
\text { students }\end{array}$ & 3 & 4 & 87,5 & $\begin{array}{l}\text { Very } \\
\text { valid }\end{array}$ \\
\hline $\begin{array}{l}\text { The material in } \\
\text { teaching materials is } \\
\text { in accordance with } \\
\text { the needs of biology } \\
\text { students }\end{array}$ & 3 & 4 & 87,5 & $\begin{array}{l}\text { Very } \\
\text { valid }\end{array}$ \\
\hline $\begin{array}{l}\text { The research results } \\
\text { presented related to } \\
\text { the material }\end{array}$ & 3 & 3 & 75 & Valid \\
\hline $\begin{array}{l}\text { Research results can } \\
\text { help students to } \\
\text { understand the }\end{array}$ & 3 & 4 & 87,5 & $\begin{array}{l}\text { Very } \\
\text { valid }\end{array}$ \\
\hline
\end{tabular}

\section{RESULT}

Based on the results of the validation of the validator, biochemical teaching materials were valid from the aspects of content, presentation, graphics, and language. The results of the validation of teaching materials by the validator in each aspect were as follows.

\subsection{Aspect of Content}

Table 3: Result of validation on the Aspect of Content. 


\begin{tabular}{|c|c|c|c|c|}
\hline material & & & & \\
\hline $\begin{array}{c}\text { The results of } \\
\text { research can make } \\
\text { teaching materials } \\
\text { more applicable }\end{array}$ & 3 & 4 & 87,5 & $\begin{array}{c}\text { Very } \\
\text { valid }\end{array}$ \\
\hline $\begin{array}{c}\text { Questions in } \\
\text { teaching materials } \\
\text { can measure student } \\
\text { knowledge about the } \\
\text { material being } \\
\text { developed }\end{array}$ & 3 & 3 & 75 & Valid \\
\hline Total & 30 & 34 & 80 & Valid \\
\hline
\end{tabular}

\subsection{Aspect of Language}

Table 4: Result of Validation on the Aspect of Language.

\begin{tabular}{|c|c|c|c|}
\hline Validated Aspect & $\begin{array}{c}\text { Valid } \\
\text { ator }\end{array}$ & $\begin{array}{c}\text { Validit } \\
\text { y value } \\
(\%)\end{array}$ & Category \\
\hline $\begin{array}{c}\text { Presentation of } \\
\text { material in textbooks } \\
\text { in accordance with } \\
\text { Indonesian rules }\end{array}$ & 3 & 75 & Valid \\
\hline $\begin{array}{c}\text { The language used in } \\
\text { communicative } \\
\text { teaching materials }\end{array}$ & 3 & 75 & Valid \\
\hline $\begin{array}{c}\text { The language used in } \\
\text { teaching materials } \\
\text { was easily to be } \\
\text { understood by } \\
\text { students }\end{array}$ & 4 & 100 & $\begin{array}{c}\text { Very } \\
\text { Valid }\end{array}$ \\
\hline $\begin{array}{c}\text { The information } \\
\text { conveyed in teaching } \\
\text { materials was clear }\end{array}$ & 3 & 75 & Valid \\
\hline Total & 13 & 81,25 & $\begin{array}{c}\text { Very } \\
\text { valid }\end{array}$ \\
\hline
\end{tabular}

\subsection{Aspect of Graphics.}

Table 5: Result of Validation on the Aspect of Graphics.

\begin{tabular}{|c|c|c|c|}
\hline Validated Aspect & $\begin{array}{c}\text { Valid } \\
\text { ator }\end{array}$ & $\begin{array}{c}\text { Validit } \\
\text { Value } \\
(\%)\end{array}$ & Category \\
\hline $\begin{array}{c}\text { The attractive design } \\
\text { of teaching materials }\end{array}$ & 3 & 75 & Valid \\
\hline $\begin{array}{c}\text { The combination of } \\
\text { colors in teaching } \\
\text { materials is } \\
\text { appropriate }\end{array}$ & 3 & 75 & Valid \\
\hline $\begin{array}{c}\text { The font size on the } \\
\text { cover and contents of } \\
\text { teaching materials was } \\
\text { proportional }\end{array}$ & 3 & 75 & Valid \\
\hline $\begin{array}{c}\text { Fonts can be read } \\
\text { clearly }\end{array}$ & 3 & 75 & Valid \\
\hline $\begin{array}{c}\text { The size of the image } \\
\text { in the teaching }\end{array}$ & 3 & 75 & Valid \\
\hline
\end{tabular}

\begin{tabular}{|c|c|c|c|}
\hline $\begin{array}{c}\text { material was in } \\
\text { accordance with the } \\
\text { size of the teaching } \\
\text { material }\end{array}$ & 3 & 75 & Valid \\
\hline $\begin{array}{c}\text { The picture presented } \\
\text { is clear }\end{array}$ & 18 & 75 & Valid \\
\hline Total &
\end{tabular}

\subsection{Aspects of Presentation}

Table 6:Result of Validation on the Aspect of Presentation.

\begin{tabular}{|c|c|c|c|}
\hline Validity Aspect & $\begin{array}{c}\text { Valid } \\
\text { ator }\end{array}$ & $\begin{array}{c}\text { Validity } \\
\text { Value } \\
(\%)\end{array}$ & $\begin{array}{c}\text { Catego } \\
\text { ry }\end{array}$ \\
\hline $\begin{array}{c}\text { Teaching materials } \\
\text { describe Learning } \\
\text { Outcomes (LO) that } \\
\text { are clearly in } \\
\text { accordance with the } \\
\text { objectives to be } \\
\text { achieved }\end{array}$ & 3 & 75 & Valid \\
\hline $\begin{array}{c}\text { The order of material } \\
\text { development is in } \\
\text { accordance with the } \\
\text { LO }\end{array}$ & 3 & 75 & Valid \\
\hline $\begin{array}{c}\text { Information on } \\
\text { teaching material } \\
\text { components is clear }\end{array}$ & 3 & 75 & Valid \\
\hline $\begin{array}{c}\text { Presentation of } \\
\text { material has given rise } \\
\text { to a stimulus for the } \\
\text { occurrence of learning } \\
\text { activities }\end{array}$ & 3 & 75 & \\
\hline $\begin{array}{c}\text { General appearance is } \\
\text { in accordance with } \\
\text { teaching material } \\
\text { standards }\end{array}$ & 3 & 75 & Valid \\
\hline $\begin{array}{c}\text { Total } \\
\text { andid }\end{array}$ & 15 & 75 & Valid \\
\hline
\end{tabular}

\section{DISCUSSION}

Based on the validation results from the validator, it was obtained that biochemical teaching materials that were valid from the aspects of content, presentation, graphics, and very valid on the overall aspects of the language. The average value of the validity of biochemical teaching materials is $77.8 \%$ with valid criteria.

The aspects of the content of the biochemical teaching materials that were developed obtained scores with valid criteria. The material developed refers to the Indonesian National Qualifications Framework (KKNI) and has been in accordance with the Learning Outcomes (LO) that need to be achieved. The substance of the material in teaching materials was in accordance with the needs of biology students who can add insight to students. the presentation of the material was equipped by the results of research related to the material that could help 
students to understand the material clarify the concept of the material being studied.

In addition, the results of research in teaching materials could add insight to students and make teaching materials more applicable. Based on the results of research from [11] it was said that the results of research as a learning resource can provide real examples for students in lectures and has the function in helping students to understand ideas and concepts. Teaching materials are also accompanied by practice questions to find out students' mastery of the material that has been learned. According to [12] the appearance of interesting teaching materials can increase and direct attention thus it can lead to learning motivation for students.

The validity of the teaching material was further viewed from the aspect of the presentation. The biochemical teaching materials that have been developed obtained validity values with the valid category from the presentation aspect. The validator assessment stated that biochemical teaching materials are valid in terms of presentation because teaching materials described the LO clearly in accordance with the goal that need to be achieved, the order of development of material in teaching materials in accordance with the LO. According to [13] the systematic presentation of material becomes an important aspect in preparing the teaching materials because the coherent arrangement of materials facilitates the material to students as a whole. Teaching materials are equipped by teaching material components which contain information on what components are contained in teaching materials tso that students are more easily familiar with teaching materials. In addition, the presentation of material in teaching materials has given rise to a stimulus for the occurrence of learning activities.

Assessment of teaching material from the validity aspect obtained values with valid criteria. Design of attractive teaching materials was in accordance with the level of students. The combination of colors contained in teaching materials was appropriate because it did not disturb the focus while reading. The font size used was in accordance with the standard size of the teaching material that can be read clearly. Teaching materials were equipped with images that were presented proportionally according to the size of the teaching material. The images contained in the teaching material were clearly visible.

Teaching materials were stated to be very valid in linguistic aspects by the validator because the presentation of material in teaching materials was generally in accordance with the good and correct Indonesian rules. The language used was communicative and easily to be understood by students. According to Hamdani (2011), one important aspect in the preparation of teaching materials is the aspect of language, by using communicative language, the material presented in teaching materials will be easily understood by students.

\section{CONCLUSION}

Biochemical teaching materials equipped by research results have met valid criteria with an average validity of $77.8 \%$. Thus it can be used in biochemical lectures.

\section{REFERENCES}

[1] Cimer, A.. What Makes Biology Learning Difficult and Effective: Student's views. Educational Research and Reviews, Vol 7 No 3.pp 61-71. 2012

[2] Depdiknas. Panduan Pengembangan Bahan Ajar, Direktorat Pembinaan SMA, Dirjen Mandikdasmen. 2008.pp 43-48

[3] Parmin, E. Prianti. Pengembangan Modul mata Kuliah Strategi Belajar Mengajar IPA Berbasis Hasil Penelitian Pembelajaran. Jurnal Pendidikan IPA Indonesia. Semarang: Universitas Negeri Semarang. 2012.pp 40-57

[4] Senaratne dan Dilanthi Amaratungga. Principles of Integrating Research Into Teaching in Higher Education: A Konowledge Transfer Perspective. United Kingdom: Univesity of Salford. 2006.pp 77-89

[5] Sudjana, Nana. Penilaian Hasil Proses Belajar Mengajar, PT. Remaja Rosdakarya. Bandung. 2001.pp 10-15

[6] Lufri dan Ardi. Metodologi Penelitian: Penelitian Kuantitatif, Penelitian Tindakan Kelas, Penelitian Pengembangan , UNP. Padang. 2014.pp 55-67

[7] Roach, M., Blackmore P, Dempster, J. Supporting High-Level Leraning Through Research Based Methods. Interim guideline for course design, TELRI Prohect University of Wrwick. 2000.pp 23-35

[8] Dekker, H dan Sylvia Walsarie Wolff. ReInventaring Research-Base Teaching and Learning. Prepared for Persentation at The Meeting of The European Forum for Enhanced Collaboration in Teaching of The European University. Brussels. 2016.pp 78-90.

[9] Griffth Institute for Higher Education. Research Based Learning: Strategies for Succesfully Linking Teaching and Research. University of Griffith. 2008.pp 20-44

[10] Plomp Tjreed dan Nieven, Nieke. Educational Design Research, Netherkands Institute for Curriculum Development (SLO). Netherlands. 2013.pp 33-65

[11] Arianti, Pebri. "Pengembangan Modul Fitopatologi Bernuansa Hasil Riset untuk Mahasiswa Biologi “. Tesis tidak diterbitkan. Padang: UNP. 2015.pp 10-16

[12] Arsyad, A. Media Pembelajaran, Rajawali Press. Jakarta. 2009.pp 14-19

[13] Prasetyo, Nugroho Aji dan Pertiwi Perwiraningtyas. 2017. "Pengembangan Buku Ajar Berbasis Lingkungan Hidup Pada Matakuliah Biologi di Universitas Tribhuwana Tunggadewi”. Jurnal Pendidian Biologi Indonesia. Vol 3 No 1. Pp 11-20 June 2017. 